\title{
Content Usage and the Most Frequently Read Articles by Issue in 2013
}

Phillip Lupo, Jr., MLIS, Anne Victoria Neale, PhD, MPH, and Marjorie A. Bowman, MD, MPA

We are pleased to provide our annual report about Fournal of the American Board of Family Medicine $(7 A B F M)$ articles published in 2013 that were of the greatest interest to our readers. Table 1 shows the 3 most frequently read articles by issue in 2013 . Original research proves to be the most-read type of article in the 2013 list.

Conflict of interest: The authors are editors and staff of the 7ABFM.
In addition, we provide an update on the usage statistics of our content over the past 8 years. Figure 1 illustrates the number of total access events for $7 A B F M$ content from 2006 to 2013. 2013 Was the busiest year for online usage activity in $7 A B F M$ 's history, with an average of 889,144 every 2 months ( $A A B F M$ is published bimonthly) and a total of 5.33 million annual content usage requests. Compare this with 14.2 million website visits per year for the weekly fournal of the American Medical Association ( $7 A M A)$ : about 284,000 visits per

Figure 1. The number of total access events for Journal of the American Board of Family Medicine content from 2006 to 2013.

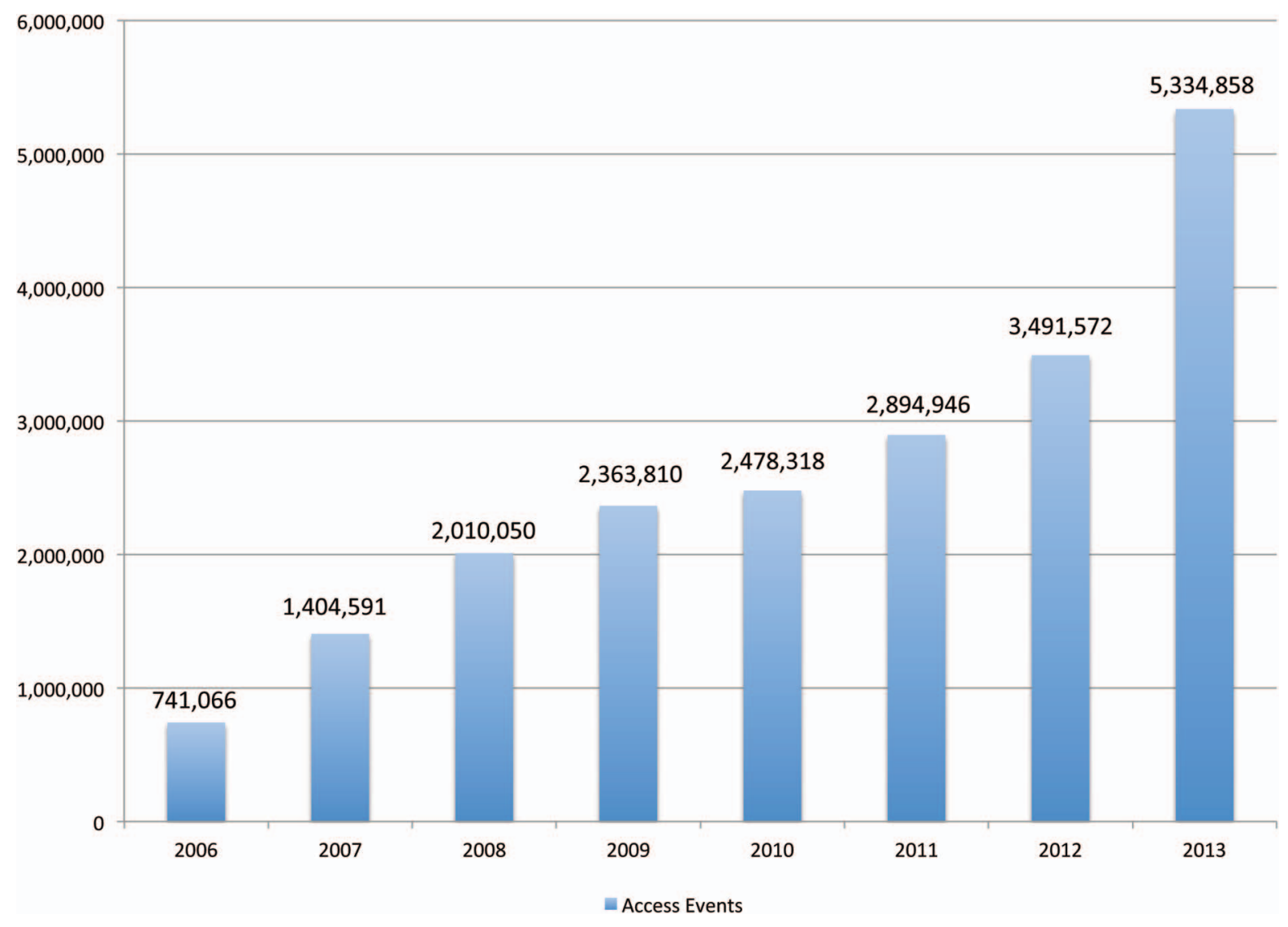


Table 1. The Three Most Frequently Read Articles in the Journal of the American Board of Family Medicine by Issue in 2013

Issue $\quad$ Article Authors and Title $\quad$ URL

January/February 2013, Volume 26, Issue 1

March/April 2013, Volume 26, Issue 2

May/June 2013, Volume 26, Issue 3

July/August 2013, Volume 26, Issue 4

September/October 2013, Volume 26, Issue 5

November/December 2013, Volume 26, Issue 6
1. Fritz DJ, Carney RM, Steinmeyer B, Ditson G, Hill N, Zee-Cheng J. The efficacy of auriculotherapy for smoking cessation: a randomized, placebo-controlled trial. ${ }^{2}$

2. Falcone JL, Middleton DB. Performance on the American Board of Family Medicine certification examination by country of medical training. ${ }^{3}$

3. Bouchard T, Fehring RJ, Schneider M. Efficacy of a new postpartum transition protocol for avoiding pregnancy. ${ }^{4}$

1. McDonald MH, Hoffman MR, Gentry LR. When is fluid in the mastoid cells a worrisome finding? ${ }^{5}$

2. Siwik V, Kutob R, Ritenbaugh C, et al. Intervention in overweight children improves body mass index (BMI) and physical activity. ${ }^{6}$

3. Painter NA, Morello CM, Singh RF, McBane SE. An evidence-based and practical approach to using Bydureon $^{\mathrm{TM}}$ in patients with type 2 diabetes. ${ }^{7}$

1. Evans D, Hartung DM, Beasley D, Fagnan LJ. Breaking up is hard to do: lessons learned from a pharma-free practice transformation. ${ }^{8}$

2. Peterson LE, Phillips RL, Puffer JC, Bazemore A, Petterson S. Most family physicians work routinely with nurse practitioners, physician assistants, or certified nurse midwives. ${ }^{9}$

3. Griswold KS, Lesko SE, Westfall JM, for the Folsom Group. Communities of solution: partnerships for population health. ${ }^{10}$

1. Falcone JL, Middleton DB. Pass rates on the American Board of Family Medicine certification examination by residency location and size. ${ }^{11}$

2. Nakawah MO, Hawkins C, Barbandi F. Asthma, chronic obstructive pulmonary disease (COPD), and the overlap syndrome. ${ }^{12}$

3. Franklin GM, Fulton-Kehoe D, Turner JA, Sullivan MD, Wickizer TM. Changes in opioid prescribing for chronic pain in Washington State. ${ }^{13}$

1. Davis M, Balasubramanian BA, Waller E, Miller BF, Green LA, Cohen DJ. Integrating behavioral and physical health care in the real world: early lessons from Advancing Care Together. ${ }^{14}$

2. Labreche MJ, Lee GC, Attridge RT, et al. Treatment failure and costs in patients with methicillin-resistant Staphylococcus aureus (MRSA) skin and soft tissue infections: a South Texas Ambulatory Research Network (STARNet) study. ${ }^{15}$

3. Bronsert MR, Henderson WG, Valuck R, Hosokawa P, Hammermeister K. Comparative effectiveness of antihypertensive therapeutic classes and treatment strategies in the initiation of therapy in primary care patients: a Distributed Ambulatory Research in Therapeutics Network (DART Net) study. ${ }^{16}$

1. Nora LM. Advancing quality health care through continuing American Board of Medical Specialties board certification. ${ }^{17}$

2. Wahlert L, Fiester A. A false sense of security: lesbian, gay, bisexual, and transgender (LGBT) surrogate health care decision-making rights. ${ }^{18}$

3. Eide MJ, Asgari MM, Fletcher SW, et al. Effects on skills and practice from a web-based skin cancer course for primary care providers. ${ }^{19}$ http://jabfm.org/content/26/1/61.full

http://jabfm.org/content/26/1/78.full

http://jabfm.org/content/26/1/35.full

http://jabfm.org/content/26/2/218.full

http://jabfm.org/content/26/2/126.full

http://jabfm.org/content/26/2/203.full

http://jabfm.org/content/26/3/332.full

http://jabfm.org/content/26/3/244.full

http://jabfm.org/content/26/3/232.full

http://jabfm.org/content/26/4/453.full

http://jabfm.org/content/26/4/470.full

http://jabfm.org/content/26/4/394.full

http://jabfm.org/content/26/5/588.full

http://jabfm.org/content/26/5/508.full

http://jabfm.org/content/26/5/529.full

http://jabfm.org/content/26/6/620.full

http://jabfm.org/content/26/6/802.full

http://jabfm.org/content/26/6/648.full

13, HighWire Press (updated monthly).

Data source: Content usage statistics for the $\mathcal{A} A B F M$, January 2013 through December 2013, HighWire Press
Rankings are based on hits received by articles archived on the $7 A B F M$ website only. Accessed 3 March 2014. 
week. ${ }^{1}$ Content activity was up $53 \%$ in 2013 compared with content usage requests during 2012 and, when compared with 2006, a $620 \%$ increase is noted. Full-text articles were the most accessed during 2013, with an average of 168,420 monthly requests; followed by abstracts, with 162,919 average monthly requests; then PDF articles, with 67,812 average monthly requests.

Full-text and PDF articles were accessed 472,464 times per issue compared with 280,000 full-text and PDF downloads per $7 A M A$ issue. ${ }^{1}$ Of note, $7 A M A$ also has 325,000 subscribers who receive the print journal per week, whereas the FABFM readership is mostly online.

As always, we welcome reader feedback about published articles. Comments about specific articles can be posted to the $7 A B F M$ website by clicking on "Responses" in the middle column of the article.

\section{References}

1. Fontanarosa PB, Bauchner H. Thank you to JAMA peer reviewers, authors, and readers. JAMA 2014; 311(7):681.

2. Fritz DJ, Carney RM, Steinmeyer B, Ditson G, Hill N, Zee-Cheng J. The efficacy of auriculotherapy for smoking cessation: a randomized, placebo-controlled trial. J Am Board Fam Med 2013;26:61-70.

3. Falcone JL, Middleton DB. Performance on the American Board of Family Medicine certification examination by country of medical training. J Am Board Fam Med 2013;26:78-81.

4. Bouchard T, Fehring RJ, Schneider M. Efficacy of a new postpartum transition protocol for avoiding pregnancy. J Am Board Fam Med 2013;26:35-44.

5. McDonald MH, Hoffman MR, Gentry LR. When is fluid in the mastoid cells a worrisome finding? J Am Board Fam Med 2013;26:218-20.

6. Siwik V, Kutob R, Ritenbaugh C, et al. Intervention in overweight children improves body mass index (BMI) and physical activity. J Am Board Fam Med 2013;26:126-37.

7. Painter NA, Morello CM, Singh RF, McBane SE. An evidence-based and practical approach to using Bydureon $^{\mathrm{TM}}$ in patients with type 2 diabetes. J Am Board Fam Med 2013;26:203-10.

8. Evans D, Hartung DM, Beasley D, Fagnan LJ. Breaking up is hard to do: lessons learned from a pharma-free practice transformation. J Am Board Fam Med 2013;26:332-8.

9. Peterson LE, Phillips RL, Puffer JC, Bazemore A, Petterson S. Most family physicians work routinely with nurse practitioners, physician assistants, or certified nurse midwives. J Am Board Fam Med 2013; 26:244-5.

10. Griswold KS, Lesko SE, Westfall JM, for the Folsom Group. Communities of solution: partnerships for population health. J Am Board Fam Med 2013; 26:232-8.

11. Falcone JL, Middleton DB. Pass rates on the American Board of Family Medicine certification exam by residency location and size. J Am Board Fam Med 2013;26:453-9.

12. Nakawah MO, Hawkins C, Barbandi F. Asthma, chronic obstructive pulmonary disease (COPD), and the overlap syndrome. J Am Board Fam Med 2013; 26:470-7.

13. Franklin GM, Fulton-Kehoe D, Turner JA, Sullivan MD, Wickizer TM. Changes in opioid prescribing for chronic pain in Washington State. J Am Board Fam Med 2013;26:394-400.

14. Davis M, Balasubramanian BA, Waller E, Miller BF, Green LA, Cohen DJ. Integrating behavioral and physical health care in the real world: early lessons from advancing care together. J Am Board Fam Med 2013;26:588-602.

15. Labreche MJ, Lee GC, Attridge RT, et al. Treatment failure and costs in patients with methicillinresistant Staphylococcus aureus (MRSA) skin and soft tissue infections: a South Texas Ambulatory Research Network (STARNet) study. J Am Board Fam Med 2013;26:508-17.

16. Bronsert MR, Henderson WG, Valuck R, Hosokawa $\mathrm{P}$, Hammermeister K. Comparative effectiveness of antihypertensive therapeutic classes and treatment strategies in the initiation of therapy in primary care patients: a Distributed Ambulatory Research in Therapeutics Network (DARTNet) study. J Am Board Fam Med 2013;26:529-38.

17. Nora LM. Advancing quality health care through continuing American Board of Medical Specialties board certification. J Am Board Fam Med 2013;26: 620-2.

18. Wahlert L, Fiester A. A false sense of security: lesbian, gay, bisexual, and transgender (LGBT) surrogate health care decision-making rights. J Am Board Fam Med 2013;26:802-4.

19. Eide MJ, Asgari MM, Fletcher SW, et al. Effects on skills and practice from a web-based skin cancer course for primary care providers. J Am Board Fam Med 2013;26:648-57. 